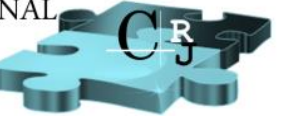

\title{
Fyzická aktivita a jóga: jejich působení na
}

\section{psychiku}

MUDr. Karel Nešpor, CSc.

\section{Úvod}

V roce 2006 jsem se ve Slovinsku zúčastnil semináře, který vedl jeden významný indický mistr¹. Mimo jiné demonstroval cvičení, o kterém tvrdil, že zpomaluje stárnutí mozku. Po návratu domů jsem se pustil do studia odborné literatury. Ke svému překvapení jsem zjistil, že fyzická aktivita mozku opravdu prospívá, a to ve více směrech (Nešpor a Csémy, 2006). Od té doby se v tomto směru objevila řada nových a prakticky užitečných poznatků.

\section{Fyzická a ktivita a psychika}

\section{Kognitivní funkce jako jsou pamět', pozornost a soustředění}

Pozitivní vliv tělesné aktivity na kognitivní funkce prokázala řada autorů. To se týká všech věkových kategorií, př́znivý účinek fyzické aktivity se zjistil u adolescentů (Subramanian a spol., 2015) i u osob nad 70 let (Bouaziz a spol., 2017). Jeden z mechanismů, jak k tomu dochází, spočívá v tom, že fyzická aktivita stimuluje sekreci BDNF (brain-derived neurotrophic factor, Heijnen a spol., 2016). BDNF napomáhá přežívání existující neuronů a podněcuje růst nových nervových buněk a synapsí.

\section{Mírnění depresivní symptomatologie}

Př́znivý vliv tělesné aktivity na depresivní symptomatologii se uplatňuje i u těžších forem depresí (Bewernick a spol., 2017). Sun a spol. (2016) použili chůzi v kombinaci s relaxační technikou a zjistili u pacientek s rakovinou prsu zmírnění deprese nižší riziko suicidálního jednání. Mírnění depresivních příznaků je užitečné samo o sobě i jako prevence postižení kognitivních funkcí ve vyšším věku (Mathersul a Rosenbaum, 2016) a předčasné smrti. K podobným závěrům dospěli i Siqueira a spol. (2016). Tito autoři navíc konstatují, že fyzická aktivita zesiluje efekt antidepresiv.

\section{Mírnění úzkosti}

Stubbs a spol. (2017) zjistili v rozsáhlé mezinárodní studii, že přiměřená fyzická aktivita je spojena s nižší mírou úzkosti. Podle citovaných autorů navíc usnadňuje fyzická aktivita sociální interakci.

\section{Tělesná aktivita a jiné emoce}

I mírná tělesná aktivita, jako je chůze, zlepšuje emoční stav (Sakuragi a Sugiyama, 2006, Yuenyongchaiwat, 2016). Hněv a nadměrná fyzická aktivita zvyšují riziko srdeční př́hody (Smyth a spol., 2016) a lze předpokládat, že kombinace obou těchto faktorů riziko ještě zvýší. Hněvu se týká i práce autorů Pels a spol. (2016). Tito autoři zjistili, že neagresivní fyzická aktivita, v jejich experimentu veslování, mírnila hněv, kdežto nácvik bojových sportů hněv neovlivnil.

\footnotetext{
${ }^{1}$ Paramahansa Niranjanananda Saraswati: Workshop Yoga - Awakening of Inner Potential, Ankaran, Slovenina 25.5. - 27.5. 2006.
} 


\section{Lepší zdravotní stav}

Tělesná aktivita je prevencí kardiovaskulárních nemocí a dalších poruch, které poškozují centrální nervový systém.

\section{Tělesná aktivita a celková relaxace}

Po skončení cvičení nastává relaxace a předchozí fyzická aktivita usnadňuje nácvik relaxačních technik. Toho se využívá v józe, kde se na závěr cvičební jednotky většinou zařazuje delší relaxace.

\section{Tělesná aktivita a bažení (craving)}

Za pomoci fyzické aktivity lze lépe zvládat bažení (craving) po návykových látkách a zlepšit kvalitu života závislých osob (Giménez-Meseguer a spol., 2015, Tritter a spol., 2015). Bažení po jídle může mírnit dokonce i jen představa oblíbené fyzické aktivity (Knäuper a spol., 2011).

\section{Zdravé sebevědomí}

Přiměřená fyzická aktivita posiluje sebevědomí mimo jiné tím, že díky ní vnímá jedinec pozitivněji své tělo a jeho možnosti (Zamani a spol., 2016).

\section{Sociální aspekty fyzické aktivity}

Při turistice nebo společném cvičené lze najít nové přátele překonat tak osamění. Vlivem sociálních faktorů mohou ale některé sporty působit i negativně, např. u dospívajících fotbalistů se zjistila v porovnání s vrstevníky vyšší spotřeba alkoholu (Nešpor a Csémy, 2016).

\section{Poznámka k vrcholovému sportu}

Vrcholový sport často představuje spíše rizikový než ochranný faktor. Soupeřivé prostředí, stres a přehnaná snaha vítězit neprospívají zdraví ani psychice. Opakovaně jsme se setkali s jedinci, kteří považovali vrcholový sport za svoji životní prioritu. Pak náhle ukončili kvůli zranění nebo nedostatečným výkonům sportovní kariéru. Jejich hodnotový systém se zhroutil. Objevily se psychické problémy a návykové nemoci.

\section{Jóga a psychika}

Velká těch, kdo praktikují jógu v Evropě, využívá tělesná cvičení. Některá z těchto cvičení kladou určité fyzické nároky a v józe se najde i řada dynamických cvičení (např. Pozdrav slunci). Výše uvedené příznivé účinky fyzické aktivity lze proto vztáhnout i na jógu.

\section{Kognitivní funkce}

Gothe a spol. (2017) zjistili př́ínivý efekt tělesných cvičení jógy na kognitivní funkce u osob vyššího věku. Goethe a spol. (2016) uvádějí, že jedním z mechanismů, jak jóga zlepšuje kognitivní funkce, je zmírnění stresu. Butzer a spol. (2016) popsali příznivý efekt jógy na soustředění u uvědomování u mladých hudebníků. U zkoumaných osob zjistili také nižší trému. Pozitivní efekt exekutivní funkce² zaznamenali u dopívajících po tři měsíce trvajícím cvičení jógy Purohit a Pradhan (2016).

\section{Mírnění depresivní a úzkostné symptomatologie}

Podobně jako fyzická aktivita i jóga mírní pocity deprese, jak o tom svědčí práce autorů Chu a spol. (2017). Helgadóttir a spol. (2016) zjistili v kontrolované studii, že jóga a aerobik mírní depresivní příznaky přibližně

\footnotetext{
${ }^{2} \mathrm{Tj}$. schopnost rozhodovat se a realizovat cílevědomé postupy a výkony, řešit problémy, tvořit analogie atd.
} 
stejně. Sharma a spol. (2017) uvádějí po dechových cvičeních jógy zlepšení u depresivních osob rezistentních vůči farmakoterapii. Morgan a spol. (2016) popsali příznivý účinek jógy u generalizované úzkostné poruchy.

\section{Relaxace}

Jóga zlepšuje uvědomování těla i psychiky. To usnadňuje celkovou i částečnou relaxaci a uvolnění za pohybu (Gaiswinkler a Unterrainer, 2016). Relaxace přináší řadu výhod sama o sobě a tím spíše v kombinaci s fyzickou aktivitou. $V$ józe navíc existuje řada postupů, jak navodit celkové uvolnění. Bhargav a spol. (2016) zjistili, že za pomoci jógové relaxace lze zlepšovat kognitivní funkce u nemocných s roztroušenou sklerózou. Takto lze také mírnit depresivní a úzkostnou symptomatologii (Rani a spol., 2012) a menstruační obtíže (Rani a spol., 2011).

\section{Mírnění bolesti}

Jedna z častých indikací relaxačních technik je mírnění bolestí různého původu (Nešpor, 1998) a v této indikaci je účinná i jóga (např. Kan a spol., 2016, a spol., 2016, Gonçalves a spol., 2017).

\section{Jóga a prevence nebo léčba návykových nemocí}

- S pomocí jógy lze účinně mírnit stres. Ten se často podílí na vzniku návykových nemocí. Návykové nemoci navíc zvyšují riziko zátěžových životních událostí, což působí další stres. Klíčovým znakem všech návykových nemocí je bažení (craving), které je provázeno stresem. Dobré zvládání stresu usnadňuje zvládání bažení a zlepšuje sebeovládání.

- Jóga a meditace také napomáhají zdravějšímu životnímu stylu a jsou užitečné jako prevence návykových nemocí (Berent a spol. 2014, Haaga a spol., 2011, Penman a spol., 2012).

- Sebeovládání úzce souvisí se sebeuvědomováním. Díky sebeuvědomování lze včas rozpoznat bažení (craving) a jiné rizikové duševní stavy, jako jsou únava nebo silné emoce. Jóga a józe blízké meditační techniky jsou v tomto směru velmi užitečné (Lyons a Cantrell, 2016, Davis a spol. 2013).

- Jóga také napomáhá rozvoji spirituality (Woodside a Culos-Reed, 2016), o jejíž prospěšnosti se zmiňujeme jinde (Nešpor, 2013).

- Jóga a jí prríbuzné metody lze při léčbě návykových nemocí kombinovat s jinými postupy (Grow a spol., 2014, Alfonso a spol., 2011), a zesilovat tak jejich efekt.

- Reddy a spol. (2014) referují o nižší spotřebě alkoholu a drog po praktikování jógy u žen s posttraumatickou stresovou poruchou. Objevily se např. zprávy o využívání jógy při zvládání odvykacích stavů (Zhuang a spol. 2013).

- Součástí jógy jsou i dechová cvičení. Shahab a spol. (2013) zjistili po jednoduchém jógovém dechovém cvičení nižší bažení po nikotinu u závislých na tabáku. Pohyb je v józe často sladěn s dechem, klade se důraz na dlouhý a úplný výdech a abdominální dýchání. Abdominální dýchání je typické pro relaxaci a má zklidňující efekt. Toho se využívá v józe i v čchi-kungu. Na nácvik abdominálního dýchání a jeho aplikaci v běžném životě klademe při práci s pacienty velký důraz. Výhodou je, že lze se takto nenápadně uklidnit a zvládnou bažení i během denních aktivit. 


\section{Vzdělávání}

Jednoduchá cvičení jógy lze dobře integrovat do vzdělávacího systému. Ferreira-Vorkapic a spol. (2015) zjistili, že se tak u žáků v porovnání s kontrolní skupinou mírnily napětí a úzkost, zvýšilo sebevědomí a zlepšila pamět'. K podobným závěrům dospěli i Sethi a spol. (2013).

\section{Další účinky}

Jóga vedla u žen vporovnání s posilovacími cvičeními květšímu sebevědomí ve vztahu k vlastnímu tělu a spokojenosti s ním. To jim poskytovalo větší jistotou při interakci s druhými lidmi (Gammage a spol., 2016). Donnelly a spol. (2016) zjistili po osmi týdnech praktikování jógy zlepšení kvality života u dospělých po úrazu mozku. Gaiswinkler a Unterrainer (2016) zjistili v porovnání s kontrolní skupinou u osob soustavně se věnujících se józe kvalitnější duchovní život, lepší uvědomování a méně depresivních příznaků. Jóga se také ukázala užitečná u osob vyššího věku s poruchami spánku (Halpern a spol., 2014).

\section{Sociální aspekty praktikování jógy}

Dobře volená cvičení jógy jsou vhodná i pro osoby vyššího věku a fyzicky méně zdatné. Při společném praktikování se rozšiřuje sít sociálních vztahů. Motivace ke cvičené jógy jsou často zdravotní a většina osob praktikujících jógu žije v porovnání s běžnou populací zdravěji, což působí příznivě i na jejich okolí.

\section{Psychologická rizika jógy a některé kontraindikace}

Osobám s psychotickým onemocněním se nedoporučují dlouhé meditace nebo relaxace. Někteří cvičenci během delší relaxace usínají, což by mohlo působit problémy v př́padě epilepsie. Pro cvičence s epilepsií nejsou vhodná také některá dechová cvičení. Specifické kontraindikace mají i další cviky, např. ty, při kterých je hlava po úrovní srdce, nejsou vhodné u osob s glaukomem. Rizika jógy jsou podstatně nižší u nižší než u většiny sportů, ale i tak je vhodná opatrnost, zvláště u osob na 65 let.

\section{Některá další józe podobná cvičení}

- S jógou má mnoho společného čchi-kung. I v něm se praktikuje uvědomovaně, často v souladu s dechem, a bývá př́tomna částečná relaxace. Existuje zde i mnoho relaxačních a meditačních technik.

- Uvědomovaně se praktikují i fyzioterapeutická cvičení. Některá z nich pocházejí z jógy nebo k ní mají blízko, jako např. pozice kobry v sestavě, jejíž autorem je McKenzie.

- Dr. Madan Kataria vytvořit tzv. „jógu smíchu“. Nejedná se o tradiční směr jógy, z vlastní zkušenosti ale víme, že smích a humor může společné cvičení jógy oživit a zpř́ijemnit (Nešpor, 2015). Kromě toho je smích užitečný při prevenci stresu a přináší i další výhody. Yim (2016) uvádí, že smích mírní biochemické změny typické pro stres, a ovlivňuje metabolismus serotoninu, dopaminu a endorfinů v mozku. Cha a Hong (2015) vysvětlují skutečnost, že smích mírní depresivní symptomatologii vlivem na metabolismus serotoninu. Smích také mírní bolest. Dunbar a spol. (2012) předpokládají, že zvýšená sekrece endorfinů při smíchu v běžném společenském životě napomáhá vytváření sociálních vazeb. Další informace o smíchu jsme zmínili jinde (Nešpor, 2016).

\section{Závěr}

Přiměřená fyzická aktivita a cvičení jógy podstatně zlepšují psychický stav a duševní výkonnost. Příznivý vliv jógy na duševní zdraví je dán kombinací více faktorů. Patří k nim kromě fyzické aktivity i celková a částečná relaxace, uvědomování, regulace dechu a spiritualita. Je žádoucí, aby zdravotníci o těchto skutečnostech věděli a vhodnou, soustavnou a pravidelnou fyzickou aktivitu doporučovali pacientům. 


\section{Literatura}

Alfonso JP, Caracuel A, Delgado-Pastor LC, Verdejo-García A. Combined goal management training and mindfulness meditation improve executive functions and decision-making performance in abstinent polysubstance abusers. Drug Alcohol Depend. 2011; 117(1):78-81.

Berent GR, Zeck JM, Leischner JA, Berent EA. Yoga as an alternative intervention for promoting a healthy lifestyle among college students. J Addict Nurs. 2014; 25(4):167-71.

Bewernick BH, Urbach AS, Bröder A a spol. Walking away from depression-motor activity increases ratings of mood and incentive drive in patients with major depression. Psychiatry Res. 2017; 247:68-72.

Bhargav P, Bhargav H, Raghuram N, Garner C. Immediate effect of two yoga-based relaxation techniques on cognitive functions in patients suffering from relapsing remitting multiple sclerosis: A comparative study. Int Rev Psychiatry. 2016; 28(3):299-308.

Bouaziz W, Vogel T, Schmitt E. a spol. Health benefits of aerobic training programs in adults aged 70 and over: a systematic review. Arch Gerontol Geriatr. 2017; 69:110-127.

Butzer B, Ahmed K, Khalsa SB. Yoga Enhances Positive Psychological States in Young Adult Musicians. Appl Psychophysiol Biofeedback. 2016; 41(2):191-202.

Davis JM, Mills DM, Stankevitz KA a spol. Pilot randomized trial on mindfulness training for smokers in young adult binge drinkers. BMC Complement Altern Med. 2013; 13:215.

Donnelly KZ, Linnea K, Grant DA, Lichtenstein J. The feasibility and impact of a yoga pilot programme on the quality-of-life of adults with acquired brain injury. Brain Inj. 2016 Dec 12:1-7. [Epub ahead of print]

Dunbar RI, Baron R, Frangou A a spol. Social laughter is correlated with an elevated pain threshold. Proc Biol Sci. 2012; 279(1731):1161-7.

Ferreira-Vorkapic C, Feitoza JM, Marchioro M a spol. Are There Benefits from Teaching Yoga at Schools? A Systematic Review of Randomized Control Trials of Yoga-Based Interventions. Evid Based Complement Alternat Med. 2015; 2015:345835.

Gaiswinkler L, Unterrainer HF. The relationship between yoga involvement, mindfulness and psychological well-being. Complement Ther Med. 2016; 26:123-7.

Gammage KL, Drouin B, Lamarche L. Comparing a Yoga Class with a Resistance Exercise Class: Effects on Body Satisfaction and Social Physique Anxiety in University Women. J Phys Act Health. 2016; 13(11):1202-1209.

Giménez-Meseguer J, Tortosa-Martínez J, de los Remedios Fernández-Valenciano M. Benefits of Exercise for the Quality of Life of Drug-Dependent Patients. J Psychoactive Drugs. 2015; 47(5):409-16.

Gonçalves AV, Barros NF, Bahamondes L. The Practice of Hatha Yoga for the Treatment of Pain Associated with Endometriosis. J Altern Complement Med. 2017; 23(1):45-52.

Gothe NP, Keswani RK, McAuley E. Yoga practice improves executive function by attenuating stress levels. Biol Psychol. 2016; 121(Pt A):109-116. 
Gothe NP, Kramer AF, McAuley E. Hatha Yoga Practice Improves Attention and Processing Speed in Older Adults: Results from an 8-Week Randomized Control Trial. J Altern Complement Med. 2017; 3; 23(1):35-40.

Grow JC, Collins SE, Harrop EN, Marlatt GA. Enactment of home practice following mindfulness-based relapse prevention and its association with substance-use outcomes. Addict Behav. 2014; 40C:16-20.

Haaga DA, Grosswald S, Gaylord-King C a spol. Effects of the Transcendental Meditation Program on Substance Use among University Students. Cardiol Res Pract. 2011; 2011:537101.

Halpern J, Cohen M, Kennedy G a spol. Yoga for improving sleep quality and quality of life for older adults. Altern Ther Health Med. 2014; 20(3):37-46.

Heijnen S, Hommel B, Kibele A, Colzato LS. Neuromodulation of Aerobic Exercise-A Review. Front Psychol. 2016; 6:1890.

Helgadóttir B, Hallgren M, Ekblom Ö, Forsell Y. Training fast or slow? Exercise for depression: A randomized controlled trial. Prev Med. 2016; 91:123-131.

Cha MY, Hong HS. Effect and Path Analysis of Laughter Therapy on Serotonin, Depression and Quality of Life in Middle-aged Women. J Korean Acad Nurs. 2015; 45(2):221-30.

Chu IH, Wu WL, Lin IM a spol. Effects of Yoga on Heart Rate Variability and Depressive Symptoms in Women: A Randomized Controlled Trial. J Altern Complement Med. 2017 Jan 4. [Epub ahead of print].

Kan L, Zhang J, Yang Y, Wang P. The Effects of Yoga on Pain, Mobility, and Quality of Life in Patients with Knee Osteoarthritis: A Systematic Review. Evid Based Complement Alternat Med. 2016; 2016:6016532.

Knäuper B, Pillay R, Lacaille J a spol. Replacing craving imagery with alternative pleasant imagery reduces craving intensity. Appetite. 2011; 57(1):173-8.

Lyons T, Cantrell WD. Prison Meditation Movements and Mass Incarceration. Int J Offender Ther Comp Criminol. 2016; 60(12):1363-75.

Mathersul DC, Rosenbaum S. The Roles of Exercise and Yoga in Ameliorating Depression as a Risk Factor for Cognitive Decline. Evid Based Complement Alternat Med. 2016; 2016:4612953.

McNamara C, Johnson M, Read L a spol. Yoga Therapy in Children with Cystic Fibrosis Decreases Immediate Anxiety and Joint Pain. Evid Based Complement Alternat Med. 2016; 2016:9429504.

Morgan JR, Sullivan M, Masuda A a spol. A Case Series on the Effects of Kripalu Yoga for Generalized Anxiety Disorder. Int J Yoga Therap. 2016; 26(1):9-19.

Nešpor K, Csémy L. Psychotropní účinky tělesné aktivity. Praktický lékař 2006, 86(11):672.

Nešpor K. Smích a medicína. Praktický lékař 2015; 95(4):187-189.

Nešpor, K.: Uvolněně a s přehledem. Relaxace a meditace pro moderního člověka. Praha: Grada 1998; 96.

Nešpor K. Spiritualita v psychiatrii. Psychiatrie pro praxi 2013; 14(2):51. 
Pels F, Kleinert J. Does Exercise Reduce Aggressive Feelings? An Experiment Examining the Influence of Movement Type and Social Task Conditions on Testiness and Anger Reduction. Percept Mot Skills. 2016; 122(3):971-87.

Penman S, Cohen M, Stevens P, Jackson S. Yoga in Australia: Results of a national survey. Int J Yoga. 2012; 5(2):92-101.

Purohit SP, Pradhan B. Effect of yoga program on executive functions of adolescents dwelling in an orphan home: A randomized controlled study. J Tradit Complement Med. 2016; 7(1):99-105.

Rani K, Tiwari S, Singh U a spol. Impact of Yoga Nidra on psychological general wellbeing in patients with menstrual irregularities: A randomized controlled trial. Int J Yoga. 2011; 4(1):20-5.

Rani K, Tiwari S, Singh U a spol.. Yoga Nidra as a complementary treatment of anxiety and depressive symptoms in patients with menstrual disorder. Int J Yoga. 2012; 5(1):52-6.

Reddy S, Dick AM, Gerber MR, Mitchell K. The effect of a yoga intervention on alcohol and drug abuse risk in veteran and civilian women with posttraumatic stress disorder. J Altern Complement Med. 2014; 20(10):750-6.

Sakuragi S, Sugiyama Y. Effects of daily walking on subjective symptoms, mood and autonomic nervous function. J Physiol Anthropol. 2006; 25(4):281-9.

Sethi JK, Nagendra HR, Sham Ganpat T. Yoga improves attention and self-esteem in underprivileged girl student. J Educ Health Promot. 2013; 2:55.

Shahab L, Sarkar BK, West R. The acute effects of yogic breathing exercises on craving and withdrawal symptoms in abstaining smokers. Psychopharmacology (Berl). 2013; 225(4):875-82.

Sharma A, Barrett MS, Cucchiara AJ a spol. A Breathing-Based Meditation Intervention for Patients With Major Depressive Disorder Following Inadequate Response to Antidepressants: A Randomized Pilot Study. J Clin Psychiatry. 2017; 78(1):e59-e63.

Schuch F, Vancampfort D, Firth J. a spol. Physical activity and sedentary behavior in people with major depressive disorder: A systematic review and meta-analysis. J Affect Disord. 2016; 210:139-150

Siqueira CC, Valiengo LL, Carvalho AF a spol. Antidepressant Efficacy of Adjunctive Aerobic Activity and Associated Biomarkers in Major Depression: A 4-Week, Randomized, Single-Blind, Controlled Clinical Trial. PLoS One. 2016; 11(5):e0154195.

Smyth A, O'Donnell M, Lamelas P. a spol. Physical Activity and Anger or Emotional Upset as Triggers of Acute Myocardial Infarction: Circulation. 2016; 134(15):1059-1067.

Stubbs B, Koyanagi A, Hallgren M. a spol. Physical activity and anxiety: A perspective from the World Health Survey. J Affect Disord. 2017; 208:545-552.

Subramanian SK, Sharma VK, Arunachalam V. a spol. Effect of Structured and Unstructured Physical Activity Training on Cognitive Functions in Adolescents - A Randomized Control Trial. J Clin Diagn Res. 2015; 9(11):CC04-9. 
Sun FK, Hung CM, Yao Y a spol. The Effects of Muscle Relaxation and Therapeutic Walking on Depression, Suicidal Ideation, and Quality of Life in Breast Cancer Patients Receiving Chemotherapy. Cancer Nurs. 2016 Dec 5. [Epub ahead of print]

Tritter A, Fitzgeorge L, Prapavessis H. The effect of acute exercise on cigarette cravings while using a nicotine lozenge. Psychopharmacology (Berl). 2015; 232(14):2531-9.

Woodside H, Culos-Reed SN. Impact of yoga on quality of life for young adult noncurative cancer patients: A pilot study. J Clin Oncol. 2016; 34(3_suppl):249.

Yim J. Therapeutic Benefits of Laughter in Mental Health: A Theoretical Review. Tohoku J Exp Med. 2016;239(3):243-9.

Yuenyongchaiwat K. Effects of 10,000 steps a day on physical and mental health in overweight participants in a community setting: a preliminary study. Braz J Phys Ther. 2016; 20:367-373.

Zamani Sani SH, Fathirezaie Z, Brand S a spol. Physical activity and self-esteem: testing direct and indirect relationships associated with psychological and physical mechanisms. Neuropsychiatr Dis Treat. 2016; $12: 2617-2625$.

Zhuang SM, An SH, Zhao Y. Yoga Effects on Mood and Quality of Life in Chinese Women Undergoing Heroin Detoxification: A Randomized Controlled Trial. Nurs Res. 2013; 62(4):260-8.

MUDr. Karel Nešpor, CSc.

Psychiatrická nemocnice Bohnice

drnespor@gmail.com

www.drnespor.eu

Received 05 Jan. 2017; Revised 08 Jan. 2017-10 Feb. 2017; Accepted 05 March 2017 